\title{
Remote sensing data for Geological mapping and gold prospecting of Inteet area, northern Sudan
}

\author{
Mohammed Ibrahim $^{1}$, Alexander Kotelnikov $^{1}{ }^{*}$, Pavel Podolko ${ }^{1}$, and Elena Kotelnikova ${ }^{1}$ \\ ${ }^{1}$ Academy of Engineering, Peoples' Friendship University of Russia (RUDN University), 6 , \\ Miklukho-Maklaya str., 117198, Moscow, Russia
}

\begin{abstract}
The mineral exploration has improved in the last decades, today there are different methods of remote exploration, that are applied in mining industry worldwide, helping to discover ore minerals deposits in zones that have not access to them. The study area of this article is located about $400 \mathrm{~km}$ from Khartoum, characterized by low reliefs covered by sand and gravely sand. The study wants to carry out the geological mapping and the prospective zones using remote sensing and GIS techniques. Sudan is characterized by geological formations over inaccessible areas, in that way the remote sensing technique has a great value in these conditions, saving time and money. The used methodology has been divided into three phases: Pre-field office work, field work and post-field work. The processing of the satellite images includes color band composites, in order to obtain the lithological and geological features, the different types of rocks were defined by a different color. Obtaining the following rock types: High-grade gneisses and migmatites described to comprise the basement complex, ophiolitic mafic-ultramafic rocks that appear in the northern and southern sides of the area, metasediments that cover most of the study area, syn-orogenic intrusions that cut the older mafic-ultramafic units and the metavolcanosedimentary sequences, postorogenic intrusions and gold mineralization. Based on the image analysis results of Landsat 8 OLI, 32 ore samples were collected to analysis gold and pathfinder elements obtaining high anomalies results for $\mathrm{Au}, \mathrm{Ag}, \mathrm{Cu}$, $\mathrm{Zn}, \mathrm{Pb}$ and $\mathrm{Fe}$.
\end{abstract}

\section{Introduction}

Mineral exploration has widely improved during the last two decades worldwide. As a result, prospectors are constantly searching newer and different technologies that can help to identify mineral deposits in a short timeframe and at reduced costs. Today, there are multiplicity of remote sensing tools available for the exploration geologists. The synthesis of the various forms of imagery, digital image processing, spectral analysis, geochemical data, office mapping and field work have been integrated together successfully with the help of GIS technology. Using remote sensing for mineral prospecting and explore new

\footnotetext{
* Corresponding author: kotelnikov-ae@rudn.ru
} 
deposits, becoming an important basic tool in mining industry worldwide, such as USA, Canada, Germany and others countries. These methods have helped to discover many minerals deposits around the world, such as gold deposits (Gossanic ridges) in Red Sea hills of NE Sudan using Landsat 8 OLI image [1,2] porphyry copper deposits, southern part of the Kerman copper belt in Iran, using Aster data [3], and detected chromite deposits in the Logar Massif, Afghanistan using Landsat-8 data [4].

Northern Sudan is known since old civilizations by its mineral potentialities particularly the precious metals, like gold.

The study area is located in North Sudan between longitudes $\left(33^{\circ} 50^{\circ}-34^{\circ} 30^{\circ}\right) \mathrm{E}$ and latitudes $\left(17^{\circ} 50^{\prime}-18^{\circ} 25^{\prime}\right) \mathrm{N}$ (fig. 1). The distance from Khartoum to the study area is about $400 \mathrm{~km}$. The area is dominated by arid climate conditions with a long hot summer season extending from March to August with temperature reaching above $45^{\circ} \mathrm{C}$ during the day, and the average temperature is about $35^{\circ} \mathrm{C}$. The winter season is from November to February and the temperature drops to less than $20^{\circ} \mathrm{C}$. The rainy season is extending from July to September with less than $200 \mathrm{~mm}$ per year rain fall. The area is very flat and poor in vegetation. Topographically, the area is characterized by low relief, except for a few isolated inselbergs. The Jebel Sutrebab ( $\sim 500 \mathrm{~m}$ high from sea level) is the most outstanding feature of the eastern side of the study area, which gradually elevates towards the Red Sea Hills. The syn-tectonic granitic intrusions, meta-volcanic, meta-sediments and sedimentary rocks dominate most of the area, and they are affected by weathering making the negative relief, also known as "depressions". Sand and gravely sands cover the southern part of the study area [5].

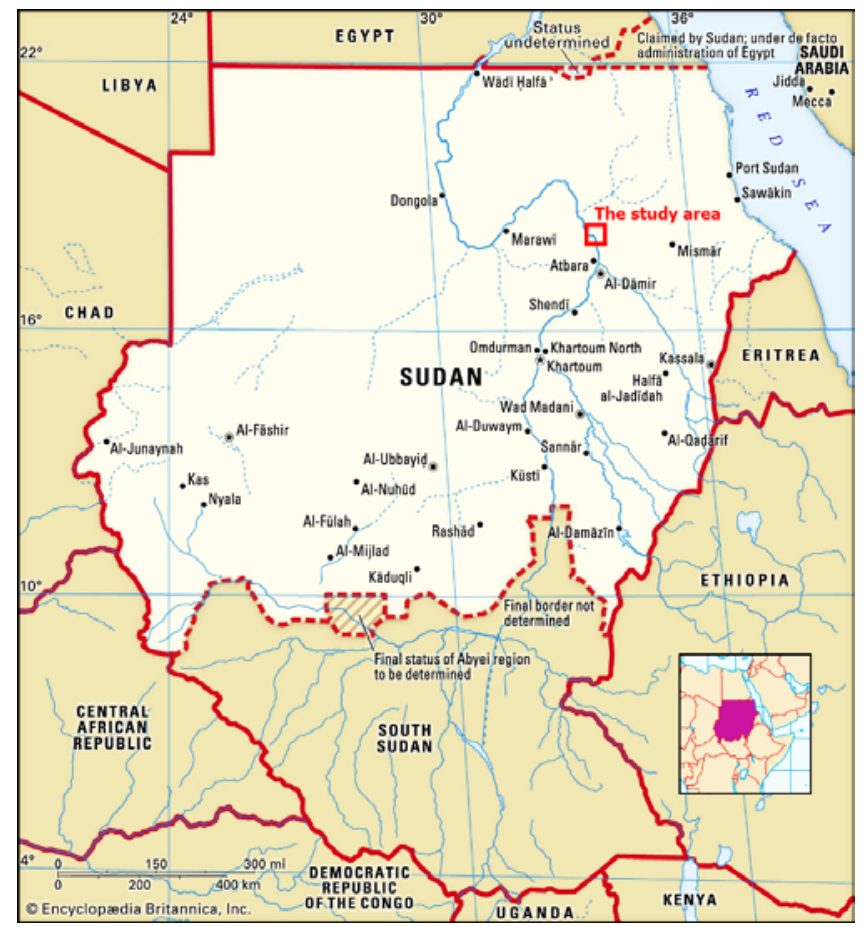

Fig. 1. Location map of the study area. 


\subsection{The objective of research}

The objective of this study is to carry out regional geological mapping and probably prospective zones for gold mineralization. An integrated approach was followed by using remote sensing and GIS techniques, as well as geological field investigations and sampling for petrographic studies and geochemical laboratory analysis.

\section{Material and Methods}

The objective of remote sensing is, generally to obtain information about objects on the earth surface from a long distance [6], also the remote sensing is defined as science of acquiring, processing and interpreting images, and related data, obtained from aircraft and satellites that record the interaction between matter and electromagnetic radiation [7].

Sudan, is a large Country characterized by many geological interesting formations scattered over inaccessible remote areas with rough terrains. The remote sensing technique has great value in such conditions. It provides a view of large regions allowing the identification of zones of interest that could be targeted by detailed investigations. The geographical information system GIS, on the other hand, allows navigation, data entry, mapping and furthermore data analysis and integration [8-11]. Indeed, this method saves time, effort and cost. In this study such kind of integrated approach was implemented in a systematic fashion. Landsat 8 OLI image processing and interpretation, field survey, rock sampling, petrographic studies and laboratory analysis were efficiently used to study the geology and gold mineralization in the study area. These methods include all laboratorial analysis used in this study, namely remote sensing and GIS analysis, petrographical and geochemical investigations of lithological units were conducted to confirm lithological discrimination, as well as the examination of the degree of alterations associated with mineralization processes [8].

Digital image processing techniques of multispectral and semi-hyperspectral remotely Sensed data integrated by the GIS techniques represent the main investigation in this study. The methodology is subdivided into three main phases.

\subsection{Pre-field office work}

This stage consisted of digital processing of Landsat-8 OLI image (open source data USGS January 2017) of the study area in order to improve the visual interpretability of the various rock groups, to help in the preparation of the preliminary geological map. The image processing was executed by several methods including: Landsat image preparation and resolution enhancement, Image enhancement (single band operations such as contrast enhancement, spatial enhancement), image transformation (multi-band operations such as color composites, image band ratios using ENVI and ERDAS IMAGINE programs). The dissimilar color composite images produced, following the methods listed above, were used to extract the geological information on the study area. Based on the spectral differences, the main rock types and general geological features. Within the area were interpreted and mapped based on the dissimilar colors before going into the field. Many waypoints were selected from the map which were determined and entered into the global positioning system (GPS) device for navigation during the field work.

\subsection{Field work}

During the field work including structural measurements, outcrop investigation, rock sampling and general prospecting for gold mineralization. A variety of samples have been 
collected for petrographic studies and geochemical for gold and associated elements analysis (Table 1).

Table 1. Description of samples collected during field work.

\begin{tabular}{|l|c|l|}
\hline \multicolumn{1}{|c|}{ Sample type } & $\begin{array}{c}\text { No. of } \\
\text { samples }\end{array}$ & \multicolumn{1}{c|}{ Purpose } \\
\hline Rock hand specimens & 11 & $\begin{array}{l}\text { Thin sectioning of representative samples for } \\
\text { petrographic study (investigate the mineral } \\
\text { compositions, textures, microstructures, degree of } \\
\text { alteration and metamorphism of rocks). }\end{array}$ \\
\hline $\begin{array}{l}\text { Chip samples from } \\
\text { quartz veins and shear } \\
\text { zones }\end{array}$ & 32 & Geochemical analysis for gold and associated elements. \\
\hline
\end{tabular}

\subsection{Post-field work}

Thin sections have been prepared at Khartoum University Laboratory, cutting and preparation the collected samples. Petrographic microscope allows investigate the mineral compositions, textures, microstructures, degree of alteration and metamorphism of rocks [12].

The collected Chip samples from quartz veins and shear zones have been prepared for geochemical analyses and these samples also have been analyzed by Atomic Absorption Spectroscopy (AAS). The results of laboratory research were studied by statistical and graphical analysis $[13,14]$.

\section{Results and Discussion}

Regional geology. The processing of satellite images includes compositing of different images and enhancement using various bands, to extract geological information on the study area. The field mapping was preceded by various digital image processing of Landsat 8 OLI images, in order to obtain the lithological and general geological features. For example, the color composite of contrast enhanced Bands 7, 4, and 2, in RGB, is shown in Figure 2 .

Sultan color composite of band ratios (5/7, 5/1 and (3/4*5/4) in RGB (Fig 3). Based on the results of this work, combined with previous geological investigations and petrographic studies of rock samples, the main rock groups in the regionally mapped area (High-grade gneisses and migmatites; Ophiolitic mafic- ultra-mafic rocks; Amphibolites; Marbles and Calc silicates; Metasediments; Syn- orogenic intrusions; Post-orogenic intrusions; Lowgrade metavolcanosedimentary sequences; Superficial deposits). Note that the gneiss appears in dark blue, the basic and ultrabasic in violet, syn-orogenic granites in white and post-orogenic granites in deep brown, Amphibolites in reddish brown, marble appear in cyan to blue and the metasediments in cyan. Rock type: Gns= Gneisses and migmatites, $\mathrm{Bsc}=$ meta-basic/ultrabasic rocks, $\mathrm{sGr}=$ Syn-orogenic granites, Amph $=$ Amphibolites, $\mathrm{Msd}=$ Metasediments, $\mathrm{Mrb}=$ marble and calc-silicates, $\mathrm{pGr}=$ Post- orogenic intrusions. 


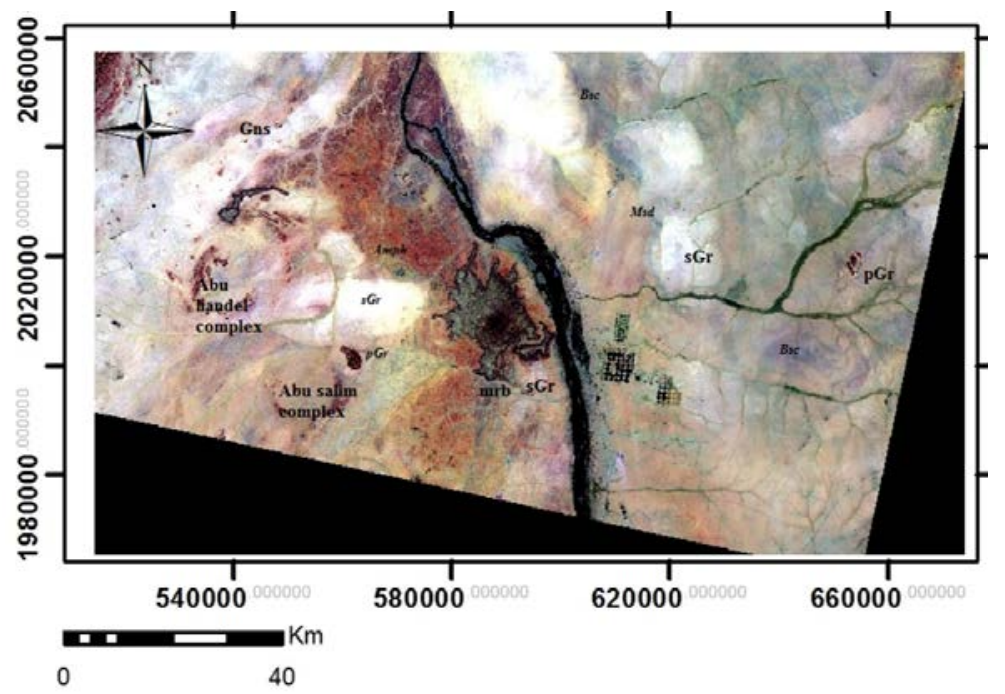

Fig. 2. Landsat 8 OLI color composite of bands 7, 4, 2 in RGB.

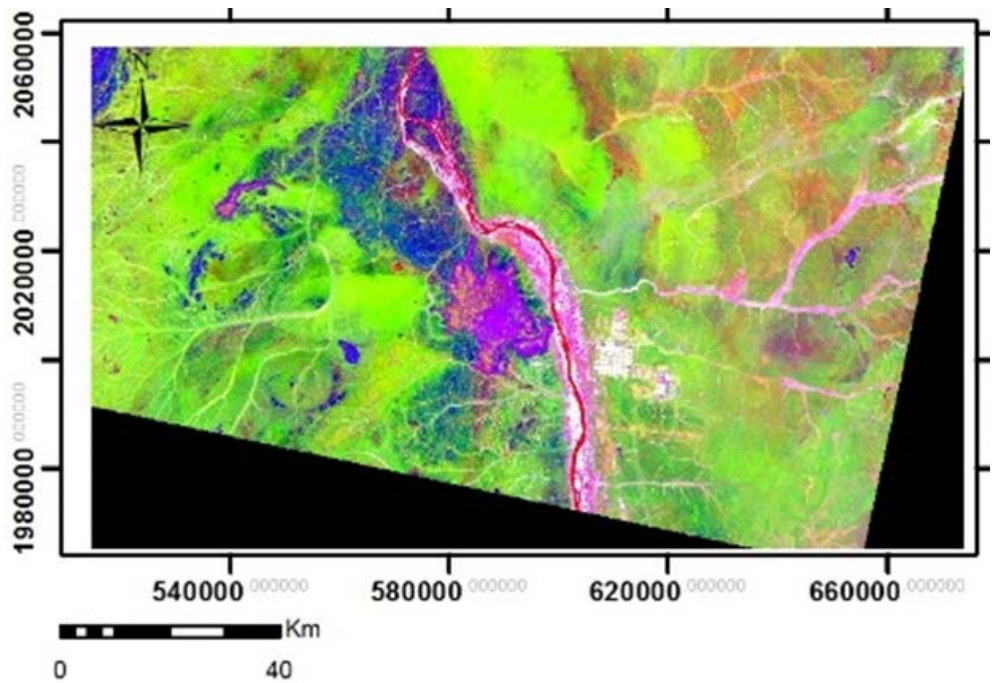

Fig. 3. Sultan color composite of band ratios (5/7, 5/1 and (3/4*5/4) in RGB.

High-grade gneisses and migmatites. The high-grade Gneisses and Migmatites, include grey gneisses, gneisses and migmatites, are well recognized in basement geology of the Sudan. They are described by many researchers to comprise the Basement Complex terranes west of the River Nile, that were repeatedly folded; poly-metamorphosed with regional N-NNE-NE-ENE trends of foliation and fold axes $[1,15]$.

In Landsat 8 OLI color composite 7, 4, 2 the gneisses appear in deep blue and light blue in sultan band ratios.

Ophiolitic mafic-ultramafic rocks. Intensely sheared and highly altered mafic-ultra mafic rocks occur in northern and southern sides of the area, in the cores of anticlinorium structures. They have been almost found in the same trend of the ophiolitic complexes (mainly Oshib ophiolites) along the Nakasib Shear Zone [16]. In Landsat 8 OLI color composite 7, 4, 2 the mafic ultramafic rocks appear in the same color in violet while in sultan band ratios ultramafic in crimson red and mafic rocks in orange-reddish. 
Metasediments. Metasediments cover most of the study area and highly sheared and altered. The rocks have been metamorphism to the green schist facies of regional metamorphism and transformed to chlorite schist and phyllites with mineral assemblages quartz, albite, chlorite, muscovite, sericite, calcite and iron ores. Several geologists have described these rocks in different parts of the Bayuda Desert. In 7, 4, 2 color composite image metasediments appear in cyan, while in sultan band ratios in cyan to yellowish-green [5].

Syn-orogenic intrusions. In the study area, intrusive rocks belong to the syn-orogenic granites, include foliated biotitegranites, biotite-muscovite granites and dioritesgranodiorite, cutting the older mafic-ultramafic units and the associated low-medium grade metavolcanosedimentary sequences. The rocks are cataclastically deformed and mylonitized by the Keraf shear zone. Syn-orogenic granites, in Landsat 8 OLI in 7, 4, 2 color composite image, appear in wide range of white while in sultan band ratios image in green.

Post-orogenic intrusions. The post-orogenic igneous complexes are widespread in the Bayuda Desert. These are signified in the study area by J. Abu Salim and J. Abu Handel. The groups range from Mid-Proterozoic to Tertiary and include gabbro, granite, syenite, syenite and carbonatite plutonic rocks, the majority in the form of ring-dykes, cone-sheets, plugs, circular intrusions, and their associated extrusive phases [17]. In 7, 4, 2 color composite image post-orogenic intrusion appear in deep brown. In sultan band ratios in blue.

Gold mineralization. Using the acquaintance about the spectral properties of rocks and minerals, Landsat 8 OLI bands $3 / 1$ and 5/7 were selected for iron oxides and hydroxyl bearing mineral. Whereas band ratio $5 / 4$ has been computed to enhance possible ferrous oxides [18].

Based on the above concepts the spectral features of ferric and hydroxyl bearing mineral, in which hydrothermally altered rocks are often rich, are used to produce a false color composite image using combinations of bands ratio 5/7, 3/1, 4/3 in RGB respectively (Fig. 4). The obtained image has mapped the alteration zone in light pink. This alteration can easily be observed in the right part of the image.

Based on the same considerations for hydrothermal combination, another image was produced using band ratios 5/7, 5/4, 3/1 in RGB respectively (Fig. 5). The obtained image has mapped the alteration zone in pink violet. This alteration can easily be observed in the right part of the image.

As knowledge of geology and mineralization of the study area and based on previous studies [19], the mineral deposit located along shear zone is associated with metasediments. Based on the results of Landsat 8 OLI interpretation 32 ore samples were collected to analysis gold and pathfinder elements (table 2). Analysis of the contrast of anomalies and the spatial combination of haloes of dispersion of elements with geological elements showed a high perspective of the area [20,21]. 


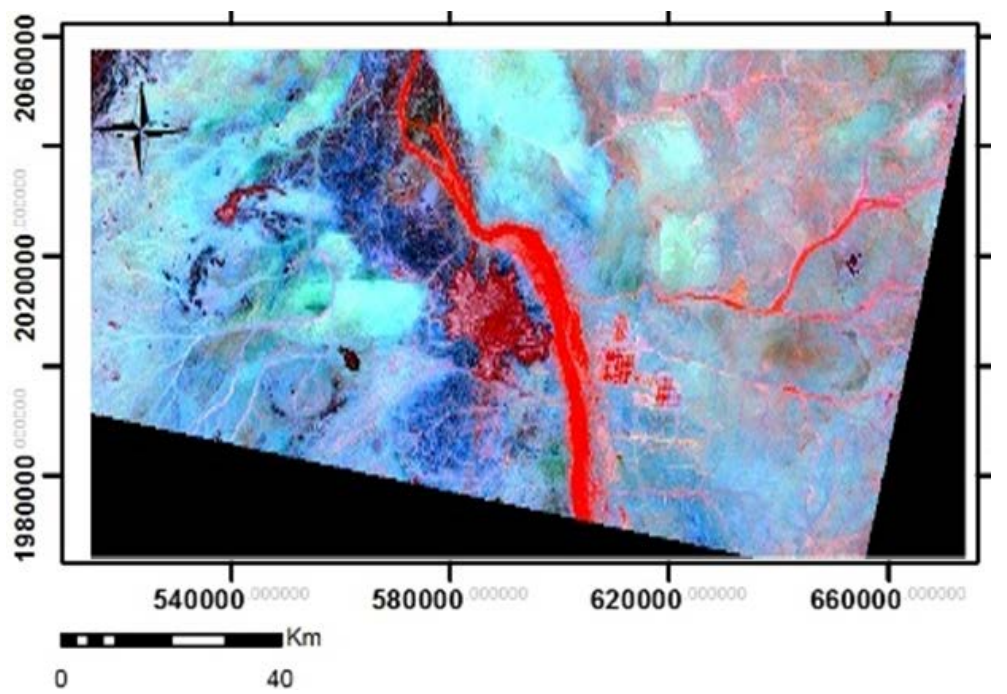

Fig. 4. Hydrothermal composite image of band ratios 5/7, 3/1, 4/3.

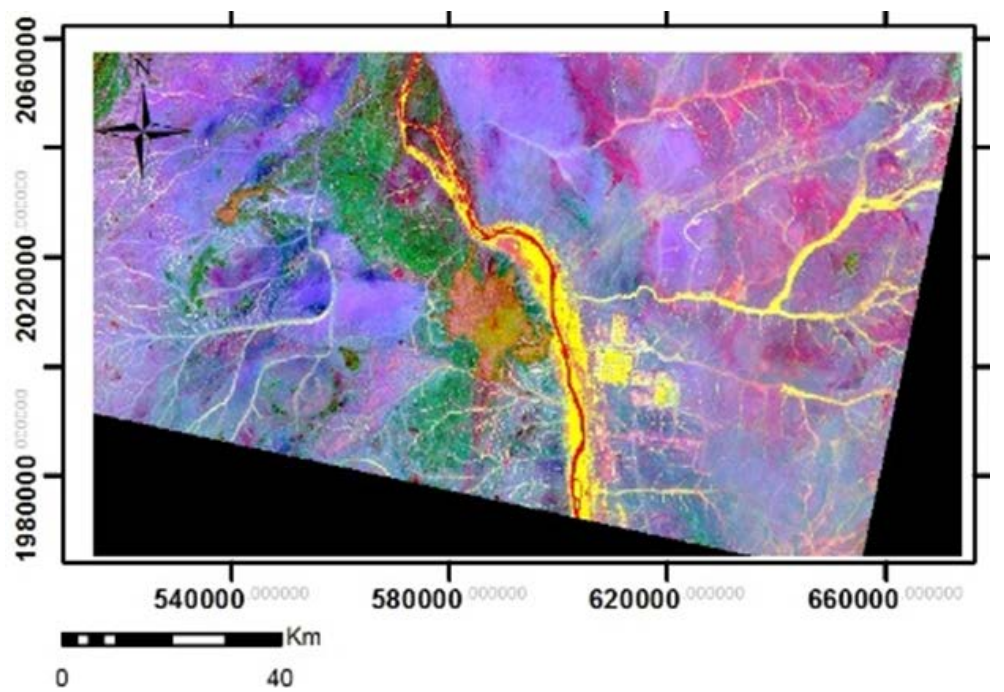

Fig. 5. Mineral composite image of band ratios 5/7, 5/4, 3/1.

Table 2. Selected of high anomalies results of chemical analysis for Pathfinders element.

\begin{tabular}{|c|c|c|c|c|c|c|}
\hline Sample ID & Au, ppm & Ag,ppm & $\mathbf{C u}, \mathbf{p p m}$ & $\mathbf{Z n}, \mathbf{p p m}$ & $\mathbf{P b}, \mathbf{p p m}$ & $\mathbf{F e}, \mathbf{\%}$ \\
\hline 89601 & 0.21 & 1.05 & 45.10 & 98.6 & 9.20 & 2.36 \\
\hline 89610 & 0.21 & 0.92 & 78.30 & 104 & 8.11 & 2.48 \\
\hline 89611 & 0.45 & 0.38 & 42.30 & 6.46 & 3.58 & 2.47 \\
\hline 89612 & 0.21 & 2.46 & 199.00 & 36.3 & 26.80 & 3.08 \\
\hline 89615 & 0.21 & 1.46 & 17.30 & 76.2 & 13.4 & 2.27 \\
\hline 89616 & 0.21 & 1.28 & 24.30 & 94.4 & 9.2 & 2.46 \\
\hline
\end{tabular}

\section{Conclusions}

Field work carried out in the study area, northern Sudan showed that the main elements of geology include layered sequences intruded by granitoids intrusions, with some tectonic 
melanges representing dismembered ophiolitic fragments. The layered sequences include high-grade gneisses and greenchist metasedimentary assemblage. Folding, faulting of different styles and the shear zone affected most of the rock groups particularly metasediments.

Petrographic study showed that the host rocks specimens are meta-sediment to metavolcanic rocks in composition, that highly deformed weathered and affected by hydrothermal alterations. The hydrothermal processes affected the area are silicification, sericitization, chloritization, epidotization and pyritization.

Therefore, the detected rock changes indicate the presence of hydrothermal systems that are of potential interest for the search for gold mineralization. The parameters of geochemical anomalies and their spatial location indicates the presence of gold mineralization in the study area.

Remote sensing combined with geological survey and laboratory analysis verified to be an effective tool for mapping geology and prospecting for gold in the Inteet area, northern Sudan. Successful similar accomplishments were reported in other similar regions of the world employing various remotely sensed data and/or different processing techniques.

\section{References}

1. A.H. El-Nadi, Colloquium on African geology 14, 95-99 (1987)

2. K.A. Elsayed Zeinelabdein, A.H. El Nadi, South American Earth Sciences 1(3), 62-67 (2014)

3. A. Masoumeh, A. Saeed, J.K. Daniel, Ore Geology Reviews 70, 290-304 (2015) DOI:10.1016/j.oregeorev.2015.04.010

4. R. Abdelaziz, Y. Abd El-Rahman, S. Wilhelm, Heliyon 4(2), e00542 (2018) doi: 10.1016/j.heliyon.2018.e00542

5. H.H. Barth, K.D. Meinhold, Mineral prospecting in the Bayuda Desert (Bundesanstalt fur Geowissenschaften und Rohstoffe, Hannover, 1979)

6. F.K. List, Fundamentals of digital image processing for geological applications (Berliner Geowiss. Abh, 1993)

7. F.F. Sabins, Remote Sensing; Principals and Interpretation (W.H. Freeman \& Co, 1997)

8. I.S. Babiker, K.A. Elsayed Zeinelabdein, A.H. El Nadi, American Journal of Earth Sciences 2(6), 171-178 (2015)

9. K.A. Elsayed Zeinelabdein, A.H. El Nadi, Am. J. Earth Sci. 1(3), 62-67 (2014)

10. E.A.H. Omer, K.A. Elsayed, Zeinelabdein Al Neelain J. Geosci. 2(1), 10-20 (2018)

11. E.A. Ali, S.O. Elkhidir, I.A.A. Babikir, E.M. Abdelrahaman, Open Remote Sens. J. 5, 83-89 (2012) DOI: 10.2174/1875413901205010083

12. L.A. Raymond, Petrology: the study of igneous, sedimentary, and metamorphic rocks (McGraw-Hill, Boston, 2007)

13. A.A. Beus, S.V. Grigorian, Geochemical Exploration Methods for Mineral Deposits (Applied Publishing Ltd, Wilmette, Illinois, 1977)

14. P. Lindagato, L. Yongjun, Y. Gaoxue, D. Fenghao, W. Zuopeng, Geologos 24(2), 95109 (2018) doi:10.2478/logos-2018-0010

15. J.R. Vail, Precambrian Research 6(1), A39-A40 (1978) doi:10.1016/03019268(78)90116-X 
16. E.M. Abdel Rahman, Geochemical and geotectonic controls of the metallogenic evolution of selected ophiolite complexes from the Sudan (Selbstverlag Fachbereich Geowissenschaften, Berlin, 1993)

17. J.R. Vail, Journal of African Earth Sciences (and the Middle East) 8(1), 19-40 (1989) doi:10.1016/S0899-5362(89)80006-5

18. G. Sohieb, A.F. Syed, A.S. Vakeel et al, International Journal of Engineering Research and Development 11(9), 01-05 (2018)

19. M.A.E. Ibrahim, A.E. Kotelnikov, S.A. Ibrahim, E.M. Kotelnikova, IOP Conference Series: Materials Science and Engineering 675, 012038 (2019) doi:10.1088/1757899X/675/1/012038

20. O.H. Sami, K. El, Y.A.G. Mohammed, E.M.E. Abdalla, A.H. Musab, A.A. Mohammed, Journal of Remote Sensing and GIS 3(1), 2052-5583 (2015)

21. V.G. Voroshilov, Geology of Ore Deposits 51(1), 1-16 (2009) doi:10.1134/S1075701509010012 